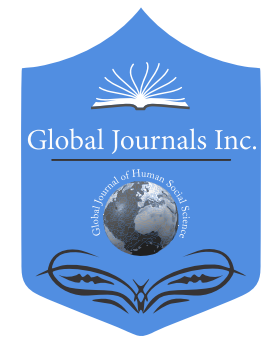

\title{
Religious Education and the Challenge of Christian-Muslim Co-Existence in Northern Nigeria
}

\author{
By Oholiabs D. Tuduks \\ Gombe State University
}

Abstract- The northern region of Nigeria where this research is concentrated is unfortunately known of a historical religious crisis which has situated the adherents in a dysfunctional relationship. Consequently, the religious groups co-exist with diverse challenges that often trigger inter-religious tension. Nigeria is generally understood as a religious country with citizens committed to the rigorous practice of their faiths. Christians and Muslims are the proliferating religious groups who co-exist as neighbors yet as rivals struggling for dominance. One of their means of propagation and indoctrination is religious education. In Nigeria, religious education takes many forms depending on the religion and whether it is moderated through government policy or privately by the religious group. However, by religious education, I refer to a formal instruction in school where particular religious adherents are taught their doctrines, beliefs, customs, rituals, rites, and other relevant themes. Exclusive religious education in some public schools is a challenge to Christian-Muslim co-existence in Nigeria.

Keywords: religious education, inter-religious learning, Christians and Muslims, Northern Nigeria.

GJHSS-A Classification: FOR Code: 220499

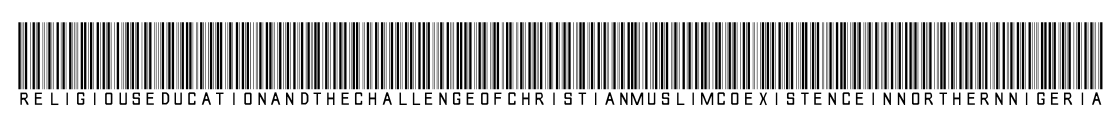

Strictly as per the compliance and regulations of:

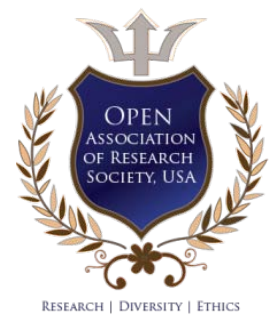

(C) 2021. Oholiabs D. Tuduks. This is a research/review paper, distributed under the terms of the Creative Commons AttributionNoncommercial 3.0 Unported License http://creativecommons.org/licenses/by-nc/3.0/), permitting all non-commercial use, distribution, and reproduction in any medium, provided the original work is properly cited. 


\title{
Religious Education and the Challenge of Christian- Muslim Co-Existence in Northern Nigeria
}

\author{
Oholiabs D. Tuduks
}

\begin{abstract}
The northern region of Nigeria where this research is concentrated is unfortunately known of a historical religious crisis which has situated the adherents in a dysfunctional relationship. Consequently, the religious groups co-exist with diverse challenges that often trigger inter-religious tension. Nigeria is generally understood as a religious country with citizens committed to the rigorous practice of their faiths. Christians and Muslims are the proliferating religious groups who co-exist as neighbors yet as rivals struggling for dominance. One of their means of propagation and indoctrination is religious education. In Nigeria, religious education takes many forms depending on the religion and whether it is moderated through government policy or privately by the religious group. However, by religious education, I refer to a formal instruction in school where particular religious adherents are taught their doctrines, beliefs, customs, rituals, rites, and other relevant themes. Exclusive religious education in some public schools is a challenge to Christian-Muslim coexistence in Nigeria. The article explores the origin, the practice, and the challenge of religious education to make a pragmatic contribution towards Christian-Muslim peaceful coexistence in the country. Inter-religious consciousness and inter-religious learning were argued as means of addressing and building bridges of functional relationship among the religious groups in Nigeria.
\end{abstract}

Keywords: religious education, inter-religious learning, Christians and Muslims, Northern Nigeria.

\section{InTRODUCTION}

N igeria has three main religious adherents: Christians, Muslims, and African traditional religionists. As the first two constitute the major ones, the last is the indigenous and first religious group in the country. Thus, Christianity and Islam are foreign religions that came to Northern Nigeria at different times. Islam preceded Christianity before the colonial era in the seventh and eighth centuries through the Arab traders via the Sahara to Kanem-Bornu, the northeastern part of the country in the present Bornu State. When British colonial administrators came to Northern Nigeria from 1900 to 1903, the Islamic rule had already been established and consolidated among the Muslims in the region (Ubah 1991). The religion of Islam integrated the various ethnic groups who were traditional religionists so that there were two broad religious communities in Northern Nigeria before the colonization - the Muslims and the adherents of the traditional religion (Turaki 1993). As part of institutionalizing the religion, the

Author: Ph.D., Department of Religious Studies, Gombe State University, Nigeria. e-mail: tuduks2013@gmail.com
Muslims established educational platforms for teaching and training religious leaders.

Similarly, when the Christian missionaries arrived, along with their primary mission, they established schools. The religious educations were going on exclusively without interest in inter-religious learning. When the government later nationalized Christian mission schools, the teaching of the two religions where introduced in all public schools with each adherents attending their religious courses. The experience reveals some challenges that affect Christian-Muslim co-existence in Nigeria. The article will explore the history of religious education in the country, its challenges, and ways of addressing them.

\section{Religious Education in Nigeria}

Before the advent of Islam and Christianity in Northern Nigeria, the indigenes already had their religion, culture and a form of informal education which enabled young people to learn different crafts and societal skills such as perseverance, hard work, and bravery. These skills equipped the people to be professional hunters, farmers, fishermen, swimmers, cooks, builders, thatcher's, hair weavers among other professions. Another form of education among the indigenous people that is still practiced to date is an event in which lessons are projected through storytelling and quizzes as theoretical classes. The practicum involves the supervision of the young people participating in the skills learned. Therefore, there were three educational traditions described as indigenous, Islamic, and Western responsible for the three religious groups: African Traditional Religion, Islam, and Christianity respectively (Ajah 2015).

Islamic education came with the learning of Arabic as the language of the Qur'an, without which adherents would not be able to read and understand it. This made the teachings of the religion and the language in primary schools carried out simultaneously (Ajah 2015). The learning of Islam and Arabic was grounded through the rigorous support from the Islamic traditional rulers with the preference the employment of only those educated in Islam and Arabic as local administrators (Mkpa 2013). The learning of both Islam and Arabic with Ulamas as instructors saturated Northern Nigeria as it is estimated; in 1914 there were about 25000 Qur'anic schools in existence in the region (Ajah 2015). After a long-standing existence of Islam 
and its traditional education, Christian missionaries arrived in the region with the gospel and education referred to as Western. The mission agency used schools as a means of religious instruction, general moral teaching, skill acquisition and elementary class. The western education floated and promoted by the foreign Christian missions was offered free while in some cases, it was highly subsidized. As a result, many Nigerian leaders today are beneficiaries of this education (Ajah 2015).

The development of the western form of education followed the nation state of amalgamation in 1914 and its subsequent independence in 1960 (Ajah 2015). Western education found full acceptance in the southern part of the country whose population is mostly Christians. On the contrary, the northern part was Muslim dominated and mostly trained in Islamic religious education. The National Population Commission (NPC 2009) records that Northern Nigeria compared with the Southern part in terms of western educational enlightenment; the south has gone far ahead with less than $20 \%$ of children who do not attend school compare to over $50 \%$ in the north. According to Tibenderana (1983), the Northern Nigerian Emirs, who before the establishment of the Northern Regional House of Assembly in 1947 were the vanguard of the northern political leadership were blamed for the western educational backwardness in Northern Nigeria. He revealed the following reasons for the blame.

1. There was no commitment by the emirs to challenge the limits of educational growth established by the government.

2. The emirs rarely pressed the British government to build more schools.

3. It was alleged that no emir throughout the British rule ever request funding towards educational development in his emirate.

4. Out of fear that the new education emerging outside the traditional Islamic class would challenge the political and religious authority, the emirs did not encourage western education development.

5. The majority of emirs, district, and village heads refrained their children from attending western education.

6. The emirs did not see the need for western education because it was only viewed as dangerous to their faith community.

7. The emirs, out of the fear of proselytization against them, discouraged their children from attending western education.

Despite the establishment of government sponsored education in 1910, it was argued that most of the emirs were reluctant to send their sons when asked to western education-based schools. They would instead send those of their slaves and servants (Tibenderana 1983). The interest was exclusively on religious education: the religion (Islam) and the language (Arabic) of the Qur'an. Over the years, awareness and enlightenment change the understanding of western education thus, the urgent need to patronize it. As a result, it was pointed out in commendation that all the First-Class Emirs of Sultan Abubakar's generation received formal western education. Only the old, between the ages of 63 and 80 by 1952 could not attend due to their ages (Tibenderana 1983). Western education continued to receive acceptance in the Northern part of Nigeria among the Muslim community. The emirs and Islamic religious leaders today do not only permit their faithful to attend western education schools, they also establish schools that run both Islamic and western education concurrently. Colleges that offered a combination of western and Islamic education for the training of Arabic teachers were also established in some states (Baba 2011). Some of the established colleges include Sokoto Arabic Teachers' College (1963), Arabic Teachers' College Gombe (1979), Arabic Teacher's College Maiduguri (1979), Arabic Teacher's College Hadejia (1979), and Arabic Teacher's College Katsina (1979) (Umar 2003). The curriculum provided proficiency in the English language, other western secular education and Arabic and Islamic education. Today, there are many government Islamic colleges existing in Northern Nigeria.

While the indigenous and Islamic forms of education continued with their respective adherents, western education was withdrawn from their custodian (the Christian missions) and nationalized (Turaki 2010). Primary education was taken over by the government in the late 1960s, and later in the early 1970s, secondary schools, teacher training colleges and hospitals were nationalized by the government. Various reasons were suggested for the withdrawal and nationalizing of schools and other institutions. It was discovered that western education was gaining more ground in the country's regions dominated by Christians (southern regions), thus the need for nationalizing western education after the independence to foster a common system of education across the country (Ajah 2015). It was also believed that public education is supposed to be government responsibility not private (Imam 2012). The other reason was the argument that Christian missions used western education as an advantage for proselytization (Turaki 2010). It was argued that the withdrawal of western education and its nationalization brought about the fallen standard of education, morality and character-building (Ajah 2015).

The fallen standard of education resulted in the proliferation of private schools, which operate with better standards than public schools. However, the major challenge of private academic institutions remains the charging of high fees that make it exclusive to the elites and well-to-do individuals. In response to the fallen 
standard of public education, there was an awakening of a return to the original owners. According to Ajah (2015), the interest and hope of having the standard of education improved prompted some state governors to accept the reversion. Ajah cited Lagos as the first state to have started the return of the schools in 2001. Other states that later followed include Imo, Ogun, Plateau, Anambra, Abia, and Delta with, for example Anambra State returning 1,040 primary schools and Delta State 40 schools to their original church owners. Supported by Nigeria Labour Congress (NLC), the government teachers protested the reversion with a threat of strike action, on the ground that the government is shying away from its responsibility of Compulsory Free Universal Basic Education Act 2004 (Osuagwu 2012). Other reasons for the protest were that the church leadership was too strict, and they made the school business a profit-oriented venture (Ajah 2015). Different religious groups assert that mission schools are better equipped than public schools and that their students perform better academically than those in public schools. These groups argue against the opinion of those who object to the reversion of the schools to their original owners and demand that the cost of education must be free or highly subsidized as in the early mission schools sponsored by foreign missionary agencies. However, it was considered that to offer and maintain quality education, payment is not negotiable (Christianity Today 2012). However, Christian communities (churches) and Muslim communities keep establishing schools alongside the government due to the fallen standard of education in public schools. Patronage of these schools depends on parents' ability to afford private schools or manage public schools.

\section{The Challenge of Religious Education in Nigeria}

Islamic Religious education originated before the colonial era in the region through the teaching of Arabic and Islam (Ajah 2015), while Christian Religious knowledge came through colonial administrations and the Christian missionaries (Ugbor 2015). During the colonial period, the teaching of the religious subjects was carried out separately in the communities of the religious groups. There were hundreds of missionary schools and many churches in the region of Northern Nigeria by the time of the national independence in 1960. However, the Muslim community did not welcome the activities of the Christian missionaries because they were in fear that their children could be converted and also felt that the region of Northern Nigeria belongs to them (Kwashi 2004). The Christian missionaries' educational policy designed a plan of addressing the divide between the two religious groups by translating the Bible into some languages, including Hausa, the Muslims' language in Northern Nigeria (Ugbor 2015).
These efforts were through Christian-Muslim cooperation supported by the Premier of Northern Nigeria, Sir Ahmadu Bello, who disclosed his intention to the Christian community that his administration would work towards reinforcing religious tolerance. The Premier appreciated the work of Christian missions and promised to continue to partner with them in the educational development of the region (Turaki 1993).

The nationalization of missionary schools enabled public schools to offer Christian religious education and Islamic religious education to respective religious students. The Islamic religious education was focused on faith and moral principles through the teaching and reading of the Qur'an, Hadith, and the Sharia (Islamic law) as a way of life. The aim of the Islamic religious education was to equip Muslim children for adult life (Ugbor 2015). In Christian religious studies, students are taught moral lessons from the Old Testament (OT), the synoptic Gospels, and the epistles on selected themes (Ugbor 2015). According to the National Policy on Education (NPE) revised in 2008, Christian Religious Studies (CRS) and Islamic Religious Studies (IRS) continue to co-exist ${ }^{1}$ in public schools as core subjects in Primary Schools. In Junior Secondary Schools (year $1-3$ ), the two religious subjects are core for all students, while in Senior Secondary Schools ${ }^{2}$ (year $4-6$ ), the religious subjects are core only to students of the humanities but indicated as compulsory subjects (NPE 2008). In practice, religious education began to experience challenges as the privileged majority religious group taught religious education exclusive of the teaching of other religion.

The reports of the Christian Solidarity Worldwide (CSW 2008) confirmed the assertion made by Kwashi (2004) about discrimination against Christians. In Katsina and Borno states, Christians complain that their children who attend public schools do not receive Christian religious teaching but, on the contrary, are forced to join Islamic religious classes. The assertion was later affirmed by the report of the $21^{\text {st }}$ century Wilberforce Initiative (2016). The CSW reports also complained that in 2004, the Katsina state government removed Christians Religious Knowledge $(\mathrm{CRK})^{3}$ as a subject of learning from the primary and secondary schools' curricula. Similarly, an Islamic scholar, Yoshau Sodiq, also noted a Christian-Muslim dysfunctional

\footnotetext{
${ }^{1}$ The co-existence of these subjects mean they are both allowed and taught, with Christians going only for CRS and Muslims taking only IRS.

2 The National Policy on Education designed the curriculum for Senior Secondary Education in accordance with the four fields of studies: Science studies, Technology studies, Humanities, and Business studies (NPE, 2008:28)

${ }^{3}$ In this work, I used Christian Religious Knowledge and Christian Religious Studies interchangeably. Similarly, I used Islamic Religious Knowledge and Islamic Religious Studies interchangeably.
} 
relationship about religious educational discrimination that a Muslim minority group suffers in a Christian majority state. Sodiq (2009) pointed out that in Christian established schools; the systems deny Muslim students of Islamic education but rather forced them to attend Christian Religious Studies. Sodiq exemplified schools like Wesley College in Oyo, St. Luke's College in Ibadan, Mount Olivet Grammar School in Ibadan, Ode-Omu (Oyo State) Community Grammar School, and Loyola College in Ibadan. The Christian-Muslim majority and minority complex in Nigeria is the main factor that spurs exclusion. For example, when Christians discover that they are the majority in a state or local government area and are in charge of leadership in public affairs, Muslims suffer exclusion. Similarly, in a Muslim dominated state Christians also become victims of exclusion. The scenario indicates that both Muslims and Christians are victims and perpetrators of religious exclusion.

The National President of Nigeria Christian Graduate Fellowship (NCGF), Prof. Charles Adeyinka Adisa, raised some concerns of religious educational exclusion. In an address ${ }^{4}$ to the then Nigerian Senate President, Senator Bukola Saraki, on behalf of the Christian Association of Nigeria (CAN), Adisa argued against the exclusion of religious education by making some observations and presenting Christian positions. He made observations from the current 9-year basic educational curriculum. The first was that CRS, which in the past used to be an independent subject, is now grouped with others ${ }^{5}$ under one main subject called Religion and National Values (Adisa 2017). The second observation concerned the content of the curriculum and the approved textbooks by the Nigerian Educational Research and Development Council (NERDC). According to Adisa, the content deliberately denigrated the person of the founder of the Christian faith. He pointed out that in IRS section in the same omnibus curriculum document, the death and resurrection of Jesus Christ is impudently denied. Thus, the denial is considered blasphemous because it is the cardinal truth of the Christian faith. Adisa explained that it would be understood if this observation was found or limited to a private religious belief, but making the statement in a national document for all faiths was obnoxious, offensive, and provocative.

Given these observations, Adisa presents the Christian consensus as follows:

\footnotetext{
${ }^{4}$ Copy of the address is available at http://kingdomnewsng.com/ news/456-position-of-christians-in-nigeria-on-the-issue-of-christianreligious-studies-as-reflected-in-the-current-9-year-basic-educationalcurriculum-presented-to-the-president-of-senate-on-wednesday-july12-2017 Accessed 10/07/2018.

${ }^{5}$ Christian Religious Studies was grouped with Islamic religious studies, Social studies, Civic education, and Security education as one main subject identified as Religion and National Values.
}

1. Scrap the omnibus subject of the nomenclature "Religion and National Values" as a subject, and in its place let there be three distinct subjects each on its own - CRS, IRS, and Social Studies. At the same time, Civic \& Security Education can be combined or made optional.

2. We demand the immediate reinstatement of CRS in the Curriculum of the States' Ministries of Education in the States that have delisted it from their school Curriculum, particularly, Kwara and Niger states, and most states in the North.

3. The Christian faith has suffered monumental damage caused by the publication and circulation of the curriculum. We consider the curriculum defamatory and demand an unreserved apology from the Federal Ministry of Education and Nigerian Educational Research and Development Council (NERDC).

4. Federal Ministry of Education and State Ministries of Education must employ religious studies teachers so that pupils and students will have the opportunity to study any religion of their choice in all public schools in Nigeria. Adisa said, "I would like to bring to your notice sir, as you may well be aware, several states in the North since the '80s have stopped employing CRS Teachers in their public schools. Some even went to the extent of coercing and flogging Christian children who refuse to do Islamic Studies. A very recent example came from your very home state, Kwara".

5. We demand that the Christian Association of Nigeria (CAN) be allowed to provide CRS Teachers in each of the states that claim they are unable to source and recruit Christian Religious Teachers. In Niger State, the Christian Association of Nigeria in the past decade had had a running battle with successive state governments over the employment of CRS Teachers in Public Schools. At some point, CAN volunteer to pay the salaries of the CRS Teachers, which the state authorities declined.

6. We demand that the Nigerian Educational Research and Development Council (NERDC) redesign the curriculum to reflect true Christian values for our children, not humanistic social/ moral instructions. This curriculum should teach them to love, respect, and revere the God of their fathers Jehovah Elohim, who sent His only begotten Son Jesus Christ to die for their sins, whose resurrection gives passport to Heaven.

7. There should be involvement of all stakeholders in reviewing the curriculum such as CAN, Nigeria Christian Graduate Fellowship, Parents Teachers Association (PTA) of Schools, and Private school proprietors. Nigerian Educational Research and Development Council (NERDC) should not at their whims and caprices hand-pick those to participate in the review. 
8. Nigerian Educational Research and Development Council (NERDC) should expunge offensive items in the curriculum that are blasphemous as a step to restoration of mutual respect.

9. Nigerian Educational Research and Development Council (NERDC) should remove morally degrading items from the textbooks.

10. NERDC should be empowered to penalize erring publishers and State Ministries of Education that violate the rules and should not be a toothless bulldog.

When a similar report appeared on social media that CRS had been scraped from the National Curriculum of Education, the rumor became a national concern as the representative of the Christian Association of Nigeria, the Nigerian House of Representative, and the Minister of education comments. In his explanation, the Minister blamed the publisher who created the confusion by producing a textbook on CRS and IRS used in some private secondary schools (Bashir 2017). According to Bashir, the minister explained his directive to schools that CRS and IRS should be taught as separate subjects. The minister explained this position in a National Television Authority (NTA) Network News Extra, ${ }^{6}$ of 21 June 2017 and highlighted that he had persuaded the National Council on Education to teach CRS and IRS compulsory to all Christian and Muslim students, respectively. However, it was later revealed that the allegation was informed by the reality of the subsuming of religious education in civic education. The issue was discussed at a plenary among the members of the House of Representatives. They condemned the government policy that allowed the subsuming of religious education in civic education as a subject (Nwabughiogu 2017). Therefore, the House agreed that CRS and IRS should be taught independently as distinct subjects. According to Emejo (2017), the accepted resolution has relatively brought the controversy over the alleged removal of CRS to an end as the new policy was set to take effect in September 2017.

\section{Towards Addressing the Challenge of Christian-Muslim Co-Existence}

Religious groups can build up inter-religious relationships through the consciousness of a pluralistic society. Inter-religious relationship speaks of the need for openness, mutual understanding and respect for one another's beliefs and practices among the adherents of religions (Bowden 2005). Christians and Muslims in Nigeria need to co-exist with a pluralistic consciousness and in inter-religious friendship. By friendship, I refer to a

\footnotetext{
${ }^{6}$ Available on YouTube at https://www.youtube.com/watch? $v=i 4 \mathrm{KXr}$ UB041g
}

relationship that allows for respect and tolerance for each other's beliefs and practices. The friendship opens room for awareness and learning from each other's traditions. As Barnes (2002) argued that Christians' calling is not only to speak about God revealed through Jesus Christ, but to also listen with generosity to what others are saying about God. Knitter (2011) agrees with Barnes and affirms that the terminology of Tillich, that if in Christian theology Christians want to explore more about 'God beyond God' than what they have discovered in Jesus Christ, then there is a need to turn and give listening ears to the experience and teachings of other religions. He adds that the Christian theology is not complete without making an effort to explore beyond the confines of the Christian boundary because the God who is beyond God is beyond all boundaries. Knowing about other religions will make Christians appreciate their unique religion (Knitter 2011). In the same way, inter-religiously, knowing about another's religion will make each religion appreciate its uniqueness.

Knitter's theology agrees with Tillich's in exploring other religious traditions, asserting that religious diversity is God's will. He explains that if religious diversity is what it is supposed to be, then the existence of people religiously should be done with consciousness and co-existence with the other religious people in different ways from theirs. Knitter expresses that "to be religious today is to be religious interreligiously." In this context, religious behavior is done inter-religiously with the consciousness of others. An inter-religiously discipline person is open-minded and has an interest in diversity, with a 'catholicity of spirit' (Little 1998). The 'catholicity of spirit' was seen in Mother Theresa, who conducted her Christian ministry interreligiously. According to Wuthnow (2005), the attendance of Mother Theresa's funeral involving representatives from the world's major religions such as Islam, Buddhism, Hinduism, and Christianity testifies of her inter-religious ministry. Inter-religious consciousness creates an inclusive mindset among the adherents of the religions where all people are seen and treated as human beings created in the image of God. Mother Theresa had such inclusive compassionate mindset that made her said, "I see God in every human being" (Wuthnow 2005). The inter-religious consciousness was first seen in the earthly life of Jesus, where he had severally cross beyond the Jewish communities in meeting the needs of others. According to Karkkainen (2013), Jesus is always available among the excluded and the outcasts, making their midst his mission field. $\mathrm{He}$ cites the lesson of the parable in Matthew 25:35-40 as a reminder that the ministry of Christians is also among the excluded where Jesus is. The application suggests inter-religious ministry with people of other religious groups through inter-religious consciousness and friendship. 
For an inter-religious lifestyle to be a matter of praxis, there are three urgent needs: building a society that is inter-religious, the need for making peace and establishing justice inter-religiously, and the need for caring for the earth inter-religiously (Knitter 2011). Interreligious lifestyles among religious groups entails interreligious engagement in dialogue and learning that will enhance and increase knowledge of one another's religious beliefs and practices (Tyagananda 2011). The reality that every religion is self-sufficient is noted by Tyagananda yet; he believes that respect for and openness to one another tends yielding new insight into one's own religious beliefs. The inter-religious lifestyle creates a peaceful society as alluded in the dictum of Hans Kung. The dictum says, "the peace among nations depends on the peace among religions, dialogue and collaboration among the religions strengthens the relationship and promotes peaceful coexistence" (Knitter 2011). Knitter explains that if there are crises among nations and ethnicities having religious causes, the solution should be from the same religion as believed by Tillich that religion should be used in fighting religion. Knitter's assertion is therefore worth affirming that if religions do not provide solution to the societal crises, they will certainly continue to exist as part of the problem. Living an inter-religious life will therefore reduce the chances of inter-religious crisis, as the case is in Nigeria.

There is a need for living with inter-religious consciousness and understanding of other religious traditions. Inter-religious understanding is an awareness that helps in appreciating the diversity which makes religious tolerance feasible. As the beauty of diversity, differences need to be celebrated as it reveals uniqueness, and the celebration will best be done through tolerance. A tolerant person suffers or endures or bears precisely by restraining rather than releasing the impulse to punish or muzzle the opponent by violence (Little 1998). The feature of tolerance as ethical behavior reveals that a person who is tolerant believes that people in a community benefit when different lifestyles can flourish (Potgieter et al. 2014). The people represent the experience of diversity where much can be learned to better the human condition. Potgieter et al. (2014) believe that the ability to allow, to permit, to comply, and to forbear constitutes a form of tolerance enjoyed in a community as the people have and exercise the right of living their own lives. Tolerance implies that we are made different (Potgieter et al. 2014). We must appreciate differences for their ability to make us develop the desire for something we do not have. The Archbishop Emeritus Desmond Tutu affirms that "differences are not intended to separate and alienate, but rather we are different precisely in order to realize our need of one another."7 The assertion of Azumah (2008) that there is a need for accurate knowledge of the beliefs and practices of Christians and Muslims is worth stressing for tolerance to flourish between the two religious groups. Therefore, I argue for inter-religious awareness and learning among the religious groups to make tolerance more feasible.

Inter-religious tolerance invites different religious groups into co-existence. Cavanagh (2012) ague the unity of religious adherents through the concept and function of religion, pointing out that the word 'religion' comes from the root 'Ligare'; a Latin term which means 'to bind together'. The term implies binding people together before binding them to God. She asserts that good religion binds people to God in a healthy manner, which means people must be helped to relate well toward others to enable them relate well to God. Cavanagh thus believes that when religion ignores people by not showing love and compassion, the most important needs of people are ultimately ignored because what brings people together is the practice of love and compassion.

The inter-religious awareness and tolerance will negate exclusive religious education in public institutions in the country. The challenge of ChristianMuslim co-existence through mono-religious educational system should be condemned because of the negative implication. It suggests that "religious education need not provide an opportunity for students to learn about other religions, come to mutual understanding, or have a dialogue with other religious believers" (Yusuf 2020). The challenge formed part of the inter-religious ignorance identified in my (Tuduks 2020) empirical research that results in the crisis among the two religious groups in Northern Nigeria.

Therefore, to encourage the co-existence of Christians and Muslims in Nigeria, there should be an intentional plan by the educational sector to be supported by the religious leaders to initiate the implementation of inter-religious learning in secondary and post-secondary institutions. The knowledge of the two religions will be taught to each religious group as 'inter-religious studies'; while the religious studies of CRS and IRS will continue as separate classes. There is also a need for the reformation of the educational curriculum on religious studies to reflect inter-religious curriculum as recommended by Sampson (2012 cf. Ugbor 2015). The teaching of inter-religious studies will include Christian and Muslim basic truths. In this way, each religious adherent will learn exactly what is taught in the other religious group. Inter-religious studies will address the problems of provocation and blasphemy

\footnotetext{
${ }^{7}$ See 'Ten Pieces of Wisdom from Desmond Tutu to inspire Change Makers in 2016'. Desmond Tutu Peace Foundation. Available at http:// www.tutufoundationusa.org/2016/01/03/ten-quotes-from-desmondtutu-to-inspire-change-makers-in-2016/ (accessed 24/03/2019).
} 
that happens because of relying on personal perception of the other religion. Unfortunately, no one knows best the religion of the other than the 'owner'. The owner should be the one to say to the other what his religion is. Therefore, the inter-religious teaching with a curriculum drawn from each respective religious group will offer accurate religious education. Inter-religious studies should thus be made available at the grassroots in public and private primary and secondary schools and a general course of study at tertiary institutions to promote Christian-Muslim inter-religious relationships. Finally, private religious institutions such as seminaries, Islamic religious schools, or religious universities should either employ $^{8}$ or invite visiting lecturers from each other's religious group to ensure there is right teaching of what is believed in each religious group. The proposal will avoid the improvising of lecturers from within a religious group to teach the religion of others which tends teaching a biased or distorted doctrine.

\section{Conclusion}

As a religious tenet, religious education is unavoidable, especially in the Nigerian context where religion is considered very sensitive. However, religious education is challenged with the practice of exclusion that introduces a mono-religious educational system in some states and local government areas populated by one religious group. The contribution of this article in the context of the challenge of Christian-Muslim coexistence includes the need for inter-religious awareness and inter-religious learning, which are crucial in motivating and creating tolerance and inter-religious friendship. The practice can avoid or drastically reduce the chances of inter-religious crisis among the religious group in Nigeria.

\section{RÉFÉRENCES}

1. Adisa, CA. (2017). Position of Christians in Nigeria on the issue of Christian religious studies as reflected in the current 9-year basic educational curriculum presented to the president of senate on Wednesday July 12, 2017. Kingdom News - Nothing but the truth. Available from: http:// kingdomnewsng. com/news/456-position-of-christians-in-nigeria-onthe-issue-of-christian-religious-studies-as-reflectedin-the-current-9-year-basic-educational-curriculumpresented-to-the-president-of-senate-onwednesday-july-12-2017 [10 July 2018].

\footnotetext{
${ }^{8}$ The employment is feasible and happening around the world with an example of Prof Yushau Sodiq, a Muslim Islamic scholar who started his teaching carrier in Nigeria with the University of Sokoto (19801983), now Usman Danfodio University Sokoto (UDUS). He specialized in Islamic Studies, Islamic law, Islam in America, and African Traditional Religions is now a lecturer at Texas Christian University teaching Islamic courses since 1992.
}

2. Ajah, M. (2015). Religious education and nationbuilding in Nigeria. Stellenbosch Theological Journal. 1(2): 263-282. DOI: http://dx.doi.org/10. 17570/stj.2015.v1n2.a12

3. Azumah, J. (2008). My neighbour's faith: Islam explained for Christians. Nairobi: Word Alive Publishers.

4. Baba, NM. (2011). Islamic schools, the Ulama, and the state in the educational development of Northern Nigeria. Bulletin de I'APAD, 33(1): 1-15. Available from: http://apad.revues.org/4092 [19 May 2018].

5. Barnes, M. (2002). Theology and the dialogue of religions. Cambridge: Cambridge University Press.

6. Bashir, M. (2017). "IRS, CRS must be taught separately in schools - Minister." Daily Trust. Available from: https://www.dailytrust.com.ng/ [25 May 2018].

7. Bowden, J. (2005). Religious pluralism and the heritage of the enlightenment, in Boase, R (ed.). Islam and global dialogue: Religious pluralism and the pursuit of peace. Farnham: Ashgate Publishing Limited. 13-20.

8. Cavanagh, L. (2012). Finding God in other Christians. London: SPCK.

9. Christianity Today (2012). "Fury over mission school fees." Christianity today. Available from: http://www. christianitytoday.com/ct/2012/june/nigeria-fury-overfees.html [25 January 2016].

10. CSW. (2008). Briefing: Nigeria, submission to United Nations Human Rights Council Universal Periodic Review. CSW Nigeria. Available from: http://lib. ohchr.org/HRBodies/UPR/Documents/Session4/ NG/C SWNGAUPR S42009anxFull Report.pdf [01 June 2017].

11. Emejo, J. (2017). "House wants religious studies, civic education taught separately." This day. Available from: https://www.thisdaylive.com/index. php/2017/07/11/house-wants-religious-studies-civic -education-taught-separately/ [12 July 2017].

12. Imam, H. (2012). Educational policy in Nigeria from the colonial era to the post-independence period. Italian Journal of Sociology of Education, 1(1): 181-204.

13. Karkkainen, V. (2013). Christ and reconciliation: A constructive Christian theology for the pluralistic world (Vol. 1). Grand Rapids: Wm. B. Eerdmans Publishing Co.

14. Knitter, PF. (2011). Doing theology interreligiously: Union and the legacy of Paul Tillich. Cross Currents, 61(1):117-132.

15. Kwashi, B. (2004). Conflict, suffering and peace in Nigeria. Transformation, 21(1):60-69.

16. Little, D. (1998). Religious tolerance and the challenge of peace: Tolerance, carefully defined, has an important role in the peaceable kingdom. Church \& Society, 88(4), 59-66. 
17. Mkpa, MA (2013). Overview of educational development: Pre-colonial to present day. Online Nigeria. Available from: https://www.onlinenigeria. com/education/?blurb=534 [23 May 2018].

18. National Policy on Education. (2008). National policy on education and 4-year strategic plan for the development of the education sector: 2011-2015 of Prof Ruqayyatu Ahmed Rufa'l, OON Honourable Minister. Lagos: Nigeria Educational Research and Development Council.

19. National Population Commission (Nigeria) \& ICF MACRO, (2009). Nigeria demographic and health survey 2008, Abuja. National Population Commission and ICF Macro. Available from: https:// www.dhsprogram.com/pubs/pdf/FR222/FR222. pdf [30 August 2019].

20. Nwabughiogu, L. (2017). "Breaking: Reps return CRK as independent subject." Vanguard Nigeria. Available from: http://www.vanguardngr.com/2017/ 07/breaking-reps-return-crk-independent-subject/ [12 July 2017].

21. Osuagwu, U (2012). The Return of mission schools: The gains, pains. Economy Nigeria. economyng. com/news162.html [12 May 2016].

22. Potgieter, FJ, van der Walt, JL \& Wolhuter, CC. (2014). Towards understanding (religious) (in) tolerance in education. HTS Teologiese Studies/ Theological Studies, 70(3): 1-8.

23. Sampson, IT. (2012). Religious violence in Nigeria: Causal diagnoses and strategic recommendations to the state and religious communities. African Journal on Conflict Resolution, 12(1): 103-134.

24. Sodiq, Y. (2009). Can Muslims and Christians live together peacefully in Nigeria? The Muslim World, 99(4): 646-688.

25. The $21^{\text {st }}$ century Wilberforce Initiative. (2016). Discrimination in Northern and Central Nigeria: Discrimination, marginalization, and persecution of religious and ethnic minorities beyond Boko Haram. $21^{\text {st }}$ Century Wilberforce Initiative. Available from: http://www.standwithnigeria.org/wp-content/ uploads/2016/12/Discrimination.pdf [01July 2017].

26. Tibenderana, PK. (1983). The Emirs and the spread of western education in Northern Nigeria. Journal of African History, 24(1): 517-534.

27. Tuduks, OD. (2020). An empirical interrogation of the Christian/Muslim inter-religious challenges in Northern Nigeria. Stellenbosch Theological Journal 6(4): 385-419. DOI: http://dx.doi.org/10.17570/stj. 2020.v6n4.a16

28. Turaki, Y. (1993). The British colonial legacy in Northern Nigeria: A social ethical analysis of the colonial and post-colonial society and politics in Nigeria. Jos: Challenge Press.

29. Turaki, Y. (2010). Tainted legacy: Islam, colonialism and slavery in Northern Nigeria. McLean: Isaac Publishing.
30. Tyagananda, S. (2011). Doing dialogue interreligiously. A Journal of Theology, 50(3): 227- 230.

31. Ubah, CN. (1991). Colonial administration and the spread of Islam in Northern Nigeria. The Muslim World, 81(2):133-148.

32. Ugbor, CA. (2015). Living the future in dialogue: Towards a new integral and transformative model of religious education for Nigeria in the $21^{\text {st }}$ century. New York: Peter Lang.

33. Umar, MS. (2003). Profiles of new Islamic schools in Northern Nigeria. The Maghreb Review, 28(2-3): 146-169.

34. Wuthnow, R. (2005). America and the challenges of religious diversity. Princeton: Princeton University Press.

35. Yusuf, M. (2020). Why Indonesia prefers a mono-religious education model? A Durkhemian perspective. Al albab 9(1): 37-54. DOI:10.24260/ alalbab.v9i1.1555 